\title{
ISLAMIC FINANCE AS AN ALTERNATIVE FUNDING SOURCE FOR AIRLINES
}

Sunder Raghavan, Embry-Riddle Aeronautical University, Daytona Beach, Florida, U.S.A. Sloane Churchill, Embry-Riddle Aeronautical University, Daytona Beach, Florida, U.S.A.

dx.doi.org/10.18374/JIFE-19-3.2

\begin{abstract}
Airlines have until recently, relied upon traditional funding sources such as bank loans, debt financing, equity financing, Enhanced Equipment Trust Certificates (EETCs), and Export-Import bank (EXIM) to fund the purchase of their aircraft. Lately, however, airlines have utilized new and innovative sources to fund the purchase of their aircraft such as schuldschein, aviation insurance consortium (AFIC) and Islamic financial products. In this paper we analyze the implication of the use of Islamic financial products as a funding source for airlines, the different institutions which formulate rules and regulations for the Islamic finance industry and analyze the risk return tradeoff between a conventional bond and an Islamic bond. Our analysis reveals that if Islamic finance has to grow as an alternative funding source for an airline, it should harmonize the conflicting directives from different regulatory institutions and ensure investors, especially non-muslim investors, are rewarded adequately for investing in Islamic financial products.
\end{abstract}

Keywords: Islamic Finance; Aircraft leasing and financing; Sukuk; ljara; Risk-Return tradeoff 